九州大学学術情報リポジトリ

Kyushu University Institutional Repository

\title{
Insect Pollination of Aqui laria crassna (Thymelaeaceae): Effect of Moths for the Fruit Setting in Thailand
}

\section{Tasen, Wattanachai}

Department of Forest Biology, Faculty of Forestry, Kasetsart University I Institute of Tropical Agriculture, Division of Bioresource and Bioenvironmental Sciences, Department of Plant Resources, Faculty of Agriculture, Kyushu University

Tangmi tcharoen, Suwan

Silviculture Research Division, Royal Forest Department

Thakeaw, Malaiporn

National Park, Wildlife and Plant Conservation Department

Ogata, Kazuo

Institute of Tropical Agriculture, Division of Bioresource and Bioenvironmental Sciences, Department of Plant Resources, Faculty of Agriculture, Kyushu University

https://doi.org/10.5109/16110

出版情報: 九州大学大学院農学研究院紀要. 54 (2)，pp.321-328，2009-10-29. Faculty of Agriculture, Kyushu University

バージョン：

権利関係 : 


\title{
Insect Pollination of Aquilaria crassna (Thymelaeaceae): Effect of Moths for the Fruit Setting in Thailand
}

\author{
Wattanachai TASEN ${ }^{1,2 *}$, Suwan TANGMITCHAROEN ${ }^{3}$, \\ Malaiporn THAKEAW ${ }^{4}$ and Kazuo OGATA ${ }^{1}$
}

\author{
Institute of Tropical Agriculture, Division of Bioresource and Bioenvironmental Sciences, \\ Department of Plant Resources, Faculty of Agriculture, \\ Kyushu University, Fukuoka 812-8581, Japan \\ (Received June 25, 2009 and accepted July 13, 2009)
}

\begin{abstract}
The diversity and abundance of insect visitors to flowers of Aquilaria crassna were investigated in a natural forest in Khao Yai National Park and a plantation in Trat Province, Thailand. The behavior and pollinating effectiveness of the major insect visitors were also examined. Data were collected from 2006 to 2008 during the flowering season from March to May. A total of 103 insect species were found, representing 34 families from 4 orders. The highest number of species belonged to the order Lepidoptera (61 species), followed by Hymenoptera (26), and Coleoptera and Diptera (8). The efficiency of moth visitors was measured by the mean number of pollen grains found on the visitor's proboscis. Endotricha species (Pyralidae, Lepidoptera) were the most abundant and frequent visitors in both areas, and had pollen deposits of 16.29 $\pm 5.36(n=9)$ grains per proboscis. Fruit setting following different pollination treatments was not significantly different in the natural forest and the plantation, and no significant difference was found between hand pollination and open pollination. However, there was a significant difference in fruit setting between hand pollination and closed pollination, indicating that pollen transfer from anthers to stigma by vectors was required for fruit setting of $A$. crassna flowers.
\end{abstract}

Keywords: insect pollinators, moths, Aquilaria crassna, pollination, fruit setting

\section{INTRODUCTION}

Successful fruit setting after pollination is important for most flowering plants. The effectiveness of animals as pollinators depends on the reproductive system of the plant (Proctor et al., 1996; Kato et al., 2003; Okamoto et al., 2008) and the availability of the associated pollinators (Richards, 1996; Grazoul et al., 1998). Insects are major pollinators of angiosperms (Proctor et al., 1996), and this includes some moth species (Proctor et al., 1996; Kato et al., 2003; Sugiura and Yamazaki, 2005; Makholela and Manning, 2006; Okamoto et al., 2008). Insect visitors vary with regard to pollination efficiency and in their preferences for floral enticements (Lau et al., 2004).

Resinous wood, mainly from the tree genus Aquilaria (Family Thymelaeaceae), is an important raw material for producing perfume and incense in the Middle East and Asia. Aquilaria crassna Pierre ex Lec. (Kritsana/ Agar Wood/ Eagle Wood) is one of the most important commercial resinous heartwood tree species. The tree is native to Cambodia, Laos, Thailand, and Vietnam (Nghia, 1998; Phengklai and Khamsai, 1985). The resinous wood of this species found in natural forests is gen-

Institute of Tropical Agriculture, Kyushu University, Fukuoka 812-8581, Japan

${ }^{2}$ Department of Forest Biology, Faculty of Forestry, Kasetsart University, Bangkok 10900, Thailand

Silviculture Research Division, Royal Forest Department, Bangkok 10900, Thailand

${ }^{4}$ National Park, Wildlife and Plant Conservation Department, Bangkok 10900, Thailand

* Correspondence author (E-mail: fforwct@ku.ac.th) erally considered to be of high quality and fetches a high price, due to its effective immune response to fungal attack (Nghia, 1998; Khangsap and Watcharinrath, 2005). In recent years, the demand for this resinous wood has increased so that the species is critically endangered, as defined by the criteria of the IUCN (International Union for Conservation of Nature) red list, and is listed in Appendix II by the Convention on International Trade in Endangered Species (CITES) of Wild Fauna and Flora (Nghia, 1998). Therefore, without a proper management and protection system, $A$. crassna may become extinct in the near future.

To address this issue, Aquilaria plantations have been expanding rapidly in Southeast Asia (Tran et al., 2003; Donovan and Puri, 2004; Khangsap and Watcharinrath, 2005). The production of high quality seeds is a key issue in the establishment of the plantation system. Low germination rate of seeds is a major problem because seed viability declines rapidly, and the proportion of viable seeds falls to $25 \%$ in the third week (Khangsap and Watcharinrath, 2005). Tissue culture is potentially an alternative way of propagating $A$. crassna but this technique requires substantial capital investment and is still in development. Thus, seed production plantations are still the most practical way to increase the quality and quantity of seed available for farmers. For effective production of large quantities of high quality seed, it is important to understand the factors affecting the pollination processes. Some research has focused on reproduction in the genus Aquilaria (Soehartono and Newton, 2001) but information on A. crassna is limited. Most members of the Thymelaeaceae family are presumed to be entomophilous (Whitehead et al., 1987) 
but the diversity and roles of the pollinators are not clear, and it is not known if there are differences between natural forests and plantations in terms of the abundance and efficiency of pollinators.

This study investigates and compares the role of pollinators during the A. crassna flowering season in canopies of natural forest and plantation stands. The diversity and abundance of flower visitors, the behavior of moth visitors to $A$. crassna flowers, and their effectiveness in pollination and fruit setting were examined.

\section{MATERIALS AND METHODS}

\section{Study site}

The study was conducted at two locations in Thailand, a natural forest at Kao Yai National Park and private plantation at Khaosaming District. Kao Yai National Park $\left(14^{\circ} 26^{\prime} \mathrm{N}, 101^{\circ} 22^{\prime} \mathrm{E}\right)$, the second largest national park in Thailand covering 216,000 ha in Nakhon Ratchasima, Saraburi, Prachinburi and Nakhon Nayok Provinces. This area holds diverse and significant habitat in tropical rain forest ecosystems, containing hill evergreen forest, dry evergreen forest, dry deciduous forest, mixed deciduous forest, secondary forests and grassland (TDRI, 1995). The elevation is about $600-700 \mathrm{~m}$ and the average annual rainfall is $1,152.8 \mathrm{~mm}$. The average annual temperature (from 1995 to 2005 ) is $26.09^{\circ} \mathrm{C}$. According to the official record, the temperatures were observed to be the highest at $33.85{ }^{\circ} \mathrm{C}$ and the lowest at $17.15^{\circ} \mathrm{C}$ in April and January, respectively (Sangtabtim, 2008). Kao Yai National Park has a wide variety of generally endangered fauna and flora, which also included A. crassna for the conservation in Thailand. In 2005 the park was designated to be an UNESCO World Heritage Site under the name Dong Phaya Yen-Khao Yai Forest Complex (United Nations, 1992-2007; DNP, 2005).
The private plantation at Khaosaming District $\left(12^{\circ}\right.$ $21^{\prime} \mathrm{N}, 102^{\circ} 29^{\prime} \mathrm{E}$ ) is located in Trat Province, eastern part of Thailand at about 15-20 m elevation, covering 12.8 ha. The average annual rainfall was $1,753.0 \mathrm{~mm}$. The climate of average annual was $28.15^{\circ} \mathrm{C}$. The highest of temperature was officially observed in May at $33.40^{\circ} \mathrm{C}$, while the lowest was in December at $22.22^{\circ} \mathrm{C}$ (Thaieasterncluster, 2008). This plantation contains 15 year old $A$. crassna trees growing at $2 \mathrm{~m} \times 4 \mathrm{~m}$ spacing.

\section{Measures of visitor species diversity}

A. crassna flowers are small $(12.1 \times 4.9 \mathrm{~mm}$ width and length) and hermaphroditic, blooming at the canopy of the tree (Fig. 1). To clarify the species diversity of flower visitors, we observed and sampled on six trees of $A$. crassna canopies in each habitat which was randomly selected based on accessibility, flowering performance and isolation. Scaffolding was erected to a height of 4 to $8 \mathrm{~m}$ around each tree.

To investigate abundance of each visitor and species richness, the insects were collected with air-flight malaise traps, which are effective in collecting Hymenoptera and Diptera (Grazoul, 1997). The flower visitors were collected every week during the flowering period. In addition, the visitor collection was supplemented by sweep net, which is rapidly swept back and forth through the canopy during night time (18:00 to 06:00) and day time (06:00 to 18:00). The number of flower visitors and their behaviors were recorded for a 20 minute period each hour. A number of individual and species, observed in ten inflorescences $(n=10)$, were recorded in the first 10 minutes while the visitor behaviors including mean time of visit (second/flower) and frequency of flower visits (number of visitors and anthesis on flowers) were then recorded in the second 10 minutes. The flowers began to open around 16:00 and most flowers opened by 18:00
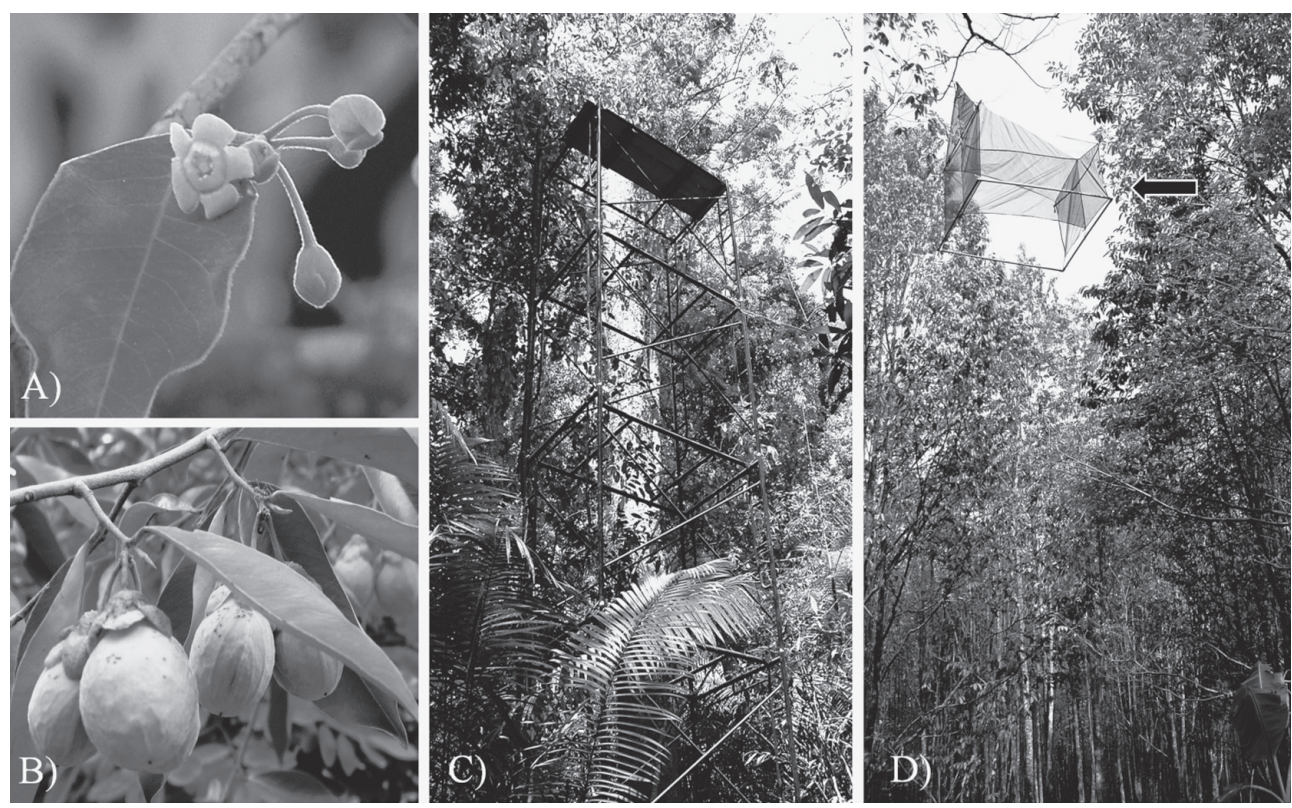

Fig. 1. Aquilaria crassna trees and collecting sites; A) flowers, B) fruits, C) a scaffolding to observe visitors at natural forest and D) an air-flight malaise trap (arrow) to catch visitors at plantation on flowering $A$. crassna canopies. 
normally. The peak blooming period of $A$. crassna is dry season. The observation was performed during March to May of three years (2006-2008). Time and areas of trapped and swept flower visitors were labeled and recorded. The visitors' species were identified at the laboratory of forest entomology, Faculty of Forestry, Kasetsart University, Thailand and Institute of Tropical Agriculture, Kyushu University, Japan.

\section{Estimation of nectar volumes and sugar concen- trations}

The volume and sugar concentration of nectar in a flower can affected a number and behavior of visitors (Heinrich and Raven, 1972; Proctor et al., 1996; Tasen et al., 2000-2002) to pollen transfer at the flower (Galen and Plowright, 1985; Thomson, 1986). To investigate the volume and quantity of nectar production by individual flower, nectar volumes and sugar concentrations were directly measured at the study site in the evening or period of each hour (16:00 to 24:00) after inflorescence starts blooming. Nectar volumes were measured by inserting a $2 \mu \mathrm{L}$ capillary tube down to the base of each flower ( $n=90$ for sugar of nectar concentration, $n=54$ for nectar volume). Because of a small amount of produced nectar, several flowers were pooled for measuring fresh nectar concentration by using a hand-held refractometer (N.O.W. Tokyo, Japan). The measurement was conducted during 27 to 30 March, in 2007 and 2008.

\section{Efficiency of flower visitors}

To investigate the potential pollination effectiveness of insect visits on the flower, direct measures were conducted by counting pollen loads on visitors to 10-15 inflorescences of each flowering trees. Firstly, unopened flowers in each inflorescence were covered with a flower bags. The bags were then opened at 18:00, which is start point of blooming. The major insect visitors were collected to examine pollen deposit on the part of body after visiting the flowers. A number of pollen grains deposited on the part of specimen were counted using a light dissecting stereomicroscope. The higher the number of pollen represents, the higher possibility of pollination resulted in higher efficiency of fruit setting. The efficiency and importance of visitors for pollination were indicated by number of pollen grain deposited on the part of the body after visiting the flowers (Moeller, 2005), which the pollen deposited or transferred by the visitor, is shown to result in fertilization of the ovule (Cox and Knox, 1988).

\section{Pollination experiments}

To detect the fruit setting in different conditions, pollination experiments were conducted in natural forest and plantation stands, which were the same sites as in the observation of flower visitors. The treatments included; (1) closed-pollination; flowers were covered by bags, (2) hand-pollination; bagged flowers were handpollinated with the pollen from a tree of more than $50 \mathrm{~m}$ distant (3) open-pollination; flowers were not covered and left open to allow the pollinators to visit freely and
(4) moth-pollination; flowers were bagged and the bags were removed at 18:00 and the flowers were tagged immediately after the moth visits. Each treatment was done on six branches of individual tree.

In the hand-pollination treatment, the undehisced stamens were removed and the flowers were bagged before flower opened between 16:00 to 17:00 on the day time. The flowers were hand-pollinated by touching the stigma with fresh-pollen from newly opened flowers. Each bag was removed for hand-pollinations from receptive flowers between 18:00 to 21:00.

The flowers of each treatment were distinguished by tagging with colored thread. All of the un-pollinated flowers were withered and fallen down during the first week (Sangtabtim, 2008). Fruit setting was recorded at two weeks after starting the pollination experiments and was calculated based on the proportion of total flowers treated.

\section{Data analyses}

Means and standard error of the means were calculated for all the measurements. The comparative means by analysis of variance (ANOVA) between natural forest and plantation stands. Duncan New Multiple Range Test at $P<0.05$ was used to compare the means and determine the significance of differences between variables.

\section{RESULTS}

\section{Diversity of flower visitors}

A total of 103 species were collected, belonging to 34 families from four insect orders; Lepidoptera, 61 species; Hymenoptera, 26 species; Diptera, 8 species; Coleoptera, 8 species (Table 1). 86 species from 33 families were found in the natural forest site, while 38 species from 15 families were found in the plantation site, and 21 species from 13 families were common to the natural forest and plantation sites.

Shannon's index of species diversity $H^{\prime}$ (Ludwig and Reynolds, 1988) was higher in the natural forest than in the plantation sites (3.61 and 3.24 respectively). The most frequent species in the forest was a pyralid moth (Xanthomelaena schematia), while Endotricha spp. was the most common species found in both the natural forest and plantation stands. Margalef's index of species abundance (Magurran, 2004) was higher in the natural forest than in the plantation (32.23 and 19.42, respectively). However, Pielou's index of species evenness (Ludwig and Reynolds, 1988) was slightly higher in the plantation than in the natural forest. This indicates that the distribution of insect visitors to both sites was not differed for variable of evenness index in floral species (Table 2).

The proportion of each species on the flowers was analyzed by Whittaker's measure of $\beta$ diversity or differentiation diversity (Whittaker, 1977). ANOVA confirmed that species richness in the natural forest was higher than in the plantation ( $F=6.267$, d.f. $=1,69, P=0.015)$. The Morisita-Horn similarity index (Wolda, 1981) for the two sites was 0.36 , a moderate to low value. 


\section{Behavior and foraging periods}

There were two peaks in the visiting times of insects (Fig. 2). The first peak was 20:00 to 22:00 and the second was 10:00 to 12:00. The number of insect visitors was lowest during 04:00 to 06:00. This pattern was the same

Table 1. Number of species and percentage of individual of insects visiting $A$. crassna flowers in natural and plantation stands ( $\mathrm{N}=$ Night time visitors, $\mathrm{D}=$ Day time visitors)

\begin{tabular}{|c|c|c|c|c|}
\hline \multirow[b]{2}{*}{ Order/Family } & \multicolumn{2}{|c|}{ Number of species } & \multirow{2}{*}{$\begin{array}{c}\text { Total } \\
\text { of } \\
\text { species }\end{array}$} & \multirow{2}{*}{$\begin{array}{c}\% \\
\text { individual } \\
\text { of visits }\end{array}$} \\
\hline & $\begin{array}{c}\text { Natural } \\
\text { forest }\end{array}$ & Plantation & & \\
\hline \multicolumn{5}{|l|}{ Lepidoptera } \\
\hline Noctuidae & $10(\mathrm{~N})$ & $5(\mathrm{~N})$ & 11 & 3.87 \\
\hline Arctiidae & $5(\mathrm{~N} / \mathrm{D})$ & $6(\mathrm{~N} / \mathrm{D})$ & 10 & 4.08 \\
\hline Pyralidae & $10(\mathrm{~N})$ & $7(\mathrm{~N})$ & 14 & 32.68 \\
\hline Lasiocampidae & $1(\mathrm{~N})$ & - & 1 & 0.14 \\
\hline Thyrididae & $1(\mathrm{~N})$ & - & 1 & 0.42 \\
\hline Geometridae & - & $1(\mathrm{~N})$ & 1 & 0.49 \\
\hline Nymphalidae & $9(\mathrm{D})$ & $4(\mathrm{D})$ & 12 & 3.59 \\
\hline Papilionidae & $1(\mathrm{D})$ & - & 1 & 0.07 \\
\hline Pieridae & $2(\mathrm{D})$ & $2(\mathrm{D})$ & 3 & 0.14 \\
\hline Lyceanidae & $6(\mathrm{D})$ & $1(\mathrm{D})$ & 6 & 0.56 \\
\hline Hesperiidae & $1(\mathrm{D})$ & - & 1 & \\
\hline Hymenoptera & & & & 2.39 \\
\hline Apidae & $6(\mathrm{D})$ & $4(\mathrm{D})$ & 7 & 5.56 \\
\hline Braconidae & $3(\mathrm{D})$ & - & 3 & 3.59 \\
\hline Chalcididae & $1(\mathrm{D})$ & - & 1 & 0.63 \\
\hline Formicidae & $5(\mathrm{D})$ & - & 5 & 1.41 \\
\hline Halictidae & $2(\mathrm{D})$ & $1(\mathrm{D})$ & 2 & 4.30 \\
\hline Megachilidae & $2(\mathrm{D})$ & - & 2 & 0.70 \\
\hline Scoliidae & $1(\mathrm{D})$ & - & 1 & 0.28 \\
\hline Sphecidae & $1(\mathrm{D})$ & - & 1 & 0.14 \\
\hline Crabronidae & $3(\mathrm{D})$ & - & 3 & 0.35 \\
\hline Vespidae & $1(\mathrm{D})$ & - & 1 & 0.56 \\
\hline \multicolumn{5}{|l|}{ Diptera } \\
\hline Culicidae & $1(\mathrm{D})$ & $1(\mathrm{D})$ & 1 & 9.08 \\
\hline Muscidae & $1(\mathrm{D})$ & $1(\mathrm{D})$ & 1 & 6.41 \\
\hline Tachinidae & $1(\mathrm{D})$ & - & 1 & 0.56 \\
\hline Tephritidae & $1(\mathrm{D})$ & $1(\mathrm{D})$ & 1 & 4.15 \\
\hline Asilidae & $1(\mathrm{D})$ & - & 1 & 0.49 \\
\hline Calliphoridae & $2(\mathrm{D})$ & $2(\mathrm{D})$ & 2 & 5.42 \\
\hline Syrphidae & $1(\mathrm{D})$ & - & 1 & 0.56 \\
\hline \multicolumn{5}{|l|}{ Coleoptera } \\
\hline Buprestidae & $2(\mathrm{D})$ & - & 2 & 0.28 \\
\hline Cerambycidae & $1(\mathrm{~N} / \mathrm{D})$ & $1(\mathrm{D})$ & 2 & 0.21 \\
\hline Chrysomelidae & $1(\mathrm{D})$ & - & 1 & 0.56 \\
\hline Coccinellidae & $1(\mathrm{D})$ & - & 1 & 0.14 \\
\hline Elateridae & $1(\mathrm{D})$ & - & 1 & 0.07 \\
\hline Scarabaeidae & $1(\mathrm{D})$ & $1(\mathrm{D})$ & 1 & 0.56 \\
\hline Total & 86 & 38 & 103 & \\
\hline
\end{tabular}

in the natural forest and plantation plots.

At night time, foraging behavior of nocturnal visitors was related to the sugar concentration and quantity of nectar secreted by the flowers. The nectar volume and sugar concentration were $0.06 \pm 0.02 \mu \mathrm{L}$ per flower and $12.54 \pm 1.22 \%$, respectively. The nectar volume was highest from 18:00 to 20:00, and the sugar concentration increased until 19:00 and then leveled off. This implies that 18:00 to 20:00 is the best time for visitors to obtain nectar from $A$. crassna flowers in terms of the quality and quantity. Indeed, the first peak of visitors almost coincides with this period, and the decrease in number of visitors paralleled the decrease in nectar volume. While the sugar concentration is not related to visitation frequency in Fig. 3 because it still remain high after 21:00.

The number of visits during the day peaked from 10:00 to 12:00. The highest number of species belonged to the order Hymenoptera, followed by Lepidoptera (butterflies), Coleoptera (beetles) and Diptera (flies). The five diurnal species contributing most flower visits were Chrysomya sp. (Calliphoridae, Diptera; $11.96 \%$ all of diurnal visits), Bactocera correcta (Tephritidae, Diptera; 11.57\%), Lasioglossum sp. (Halictidae, Hymenoptera; 10.20\%), Apis florea (Apidae, Hymenoptera; 5.69\%)

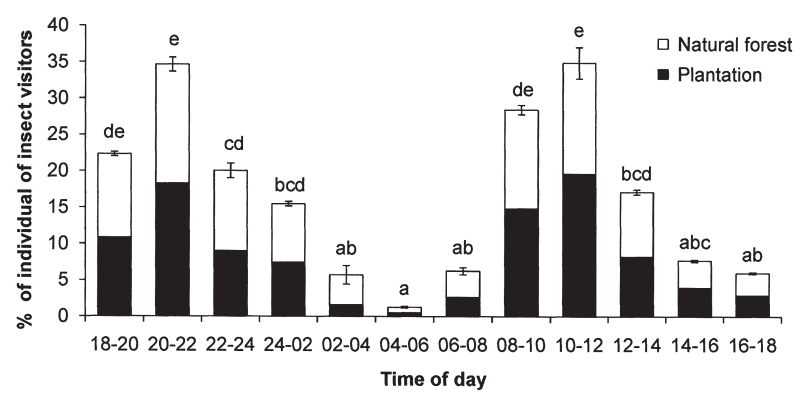

Fig. 2. Numbers of insect visitors in different flowering periods in the natural forest and the plantation. Vertical bars show the standard error of the mean for each variable. The same letter indicates the means are not significantly different at $P<0.05$ as determined by Duncan's New Multiple Range Test.

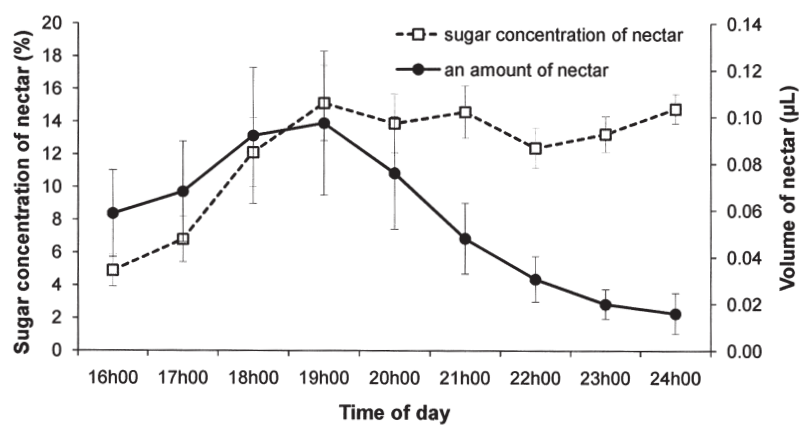

Fig. 3. Relationship between sugar concentration of nectar (\%) and the volume of nectar $(\mu \mathrm{L})$ in $A$. crassna flowers in each observation period from 16:00 to 24:00 h. Vertical bars show the standard error of the mean for each variable. 
Table 2. Number of individuals and species diversity indices of insect visitors collected from A. crassna flowers in natural and plantation stands

\begin{tabular}{lccccc}
\hline \multirow{2}{*}{ Habitat } & \multirow{2}{*}{ Number of individuals } & \multicolumn{4}{c}{ Diversity indices } \\
\cline { 3 - 6 } & & $H^{\prime}$ (Shannon's index) & Evenness & Richness & $\beta$ diversity \\
\hline Natural forest & 1039 & 3.61 & 0.52 & 32.23 & 7.76 \\
Plantation & 377 & 3.24 & 0.55 & 19.42 & 4.26 \\
\hline
\end{tabular}

and Catopsilia pomona (Pieridae, Lepidoptera; 5.29\%). The diurnal visitors can potentially support or assist pollination of $A$. crassna flowers not pollinated by nocturnal visitors. The present study indicates that the diurnal insect groups were mostly present before noon in both the natural forest and plantation.

The mean duration of visits in the natural forest and plantation were not significantly different $(F=1.04$, d.f. $=1$, $11, P=0.461$ ), but the foraging behaviors of the nocturnal and the diurnal pollinators were different $(F=44.03$, d.f.=1, 11, $P=0.000)$. The mean duration of visits of the nocturnal visitors or moths was $25.36 \pm 1.78$ second per flower $(n=46)$ while the mean duration of visits of the Hymenopteran (wild bees, wasps and ants) diurnal visitors was $10.39 \pm 0.70$ second per flower $(n=40)$. Mean visit durations of Lepidoptera (butterflies), Coleoptera (beetles) and Diptera (flies) were 10.94 $\pm 0.17(\mathrm{n}=110)$, $11.28 \pm 0.59(n=3)$ and $11.93 \pm 2.66(n=22)$ second per flower respectively. The staying time on a flower is significantly longer for the nocturnal visitors. The quality and quantity of nectar of $A$. crassna flowers were not measured in the day time, but it is certain that the volume of nectar is distinctly lower than at night, which may be why the diurnal visitors stay on flowers for a relatively short time.

\section{Efficiency of flower visitors}

Examination of the pollination efficiency of insect visitors mainly focused on the nocturnal visitors, since the highest number pollen grains were found on the proboscis of this group (Fig. 4). The highest number of pollen grain deposited on the proboscis per individual was found in the noctuid moth (Parallelia rigidistria) (25.57 $\pm 8.01, \mathrm{n}=7$ ).

The second and third highest numbers of pollen grains were found on the proboscis of the pyralid moths
Salma sp. (18.17 $\pm 10.85, \mathrm{n}=6)$ and Sameodes cancellalis $(17.67 \pm 2.60, \mathrm{n}=3)$, However, the lowest number of pollen grains found per proboscis was recorded in Endotricha species (16.29 $\pm 5.36, \mathrm{n}=9)$, the most frequent and abundant species in both the natural forest and plantation (Table 3). Xanthomelaena schematias spent the longest time foraging and the mean duration of visits was $30.64 \pm 4.59$ second per flower $(n=11)$, and the lowest number of pollen grains per proboscis (3.86 \pm 1.30 , $\mathrm{n}=17$ ), were found on this species.

\section{Pollination experiments}

Fruit setting in $A$. crassna was not significantly different $(F=3.96$, d.f. $=3, P=0.109)$ in the natural forest and plantation. However, there was a significant difference between treatments $(F=37.97$, d.f. $=3, P=0.002)$. Fruit setting in the closed pollination treatment $(0.53 \%)$ was significantly lower than in the hand pollination treatment $(3.62 \%)$. Fruit setting in the hand pollination and open pollination treatments was not significantly different. This indicates that fruit set do not restricted by pollen lacking and pollen transfer from anthers to stigma by vectors is required for fruit setting in A. crassna. Fruit setting by moth pollination was higher than in the closed-pollination treatment, but the difference was not statistically significant $(F=1.99$, d.f. $=3, P=0.117)$.

Flower visitors in the open pollination treatment were not directly observed, but the treatment allows for the influence of insect visitors in pollination. Fruit setting in moth-pollination was not significantly lower than in open-pollination in both the natural forest and plantation. In the natural forest, fruit setting of moth pollinated trees was $1.09 \%$ compared to $2.23 \%$ in open pollinated trees. In the plantation, fruit setting in moth pollinated trees was $1.33 \%$ compared to $2.78 \%$ in open pollinated trees (Fig. 5).
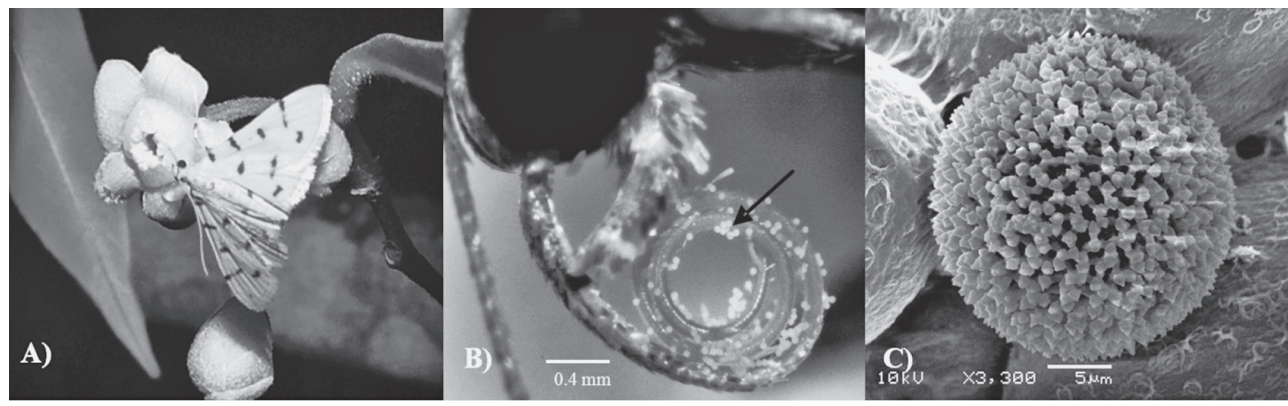

Fig. 4. Moth visitor and pollen grain of A. crassna flower; A) Endotricha species visiting on flower, B) pollen grains deposited on proboscis of a pyralid moth (arrows) and C) scanning electron micrographs (SEM) of pollen grain. 
Table 3. Mean $( \pm \mathrm{SE})$ time of visit and mean $( \pm \mathrm{SE})$ number of pollen grains on proboscis of ten moth visitors during 18:00 to 22:00 found in the natural forest and the plantation

\begin{tabular}{|c|c|c|c|c|}
\hline Family/ Species & $\begin{array}{l}\text { Mean time of visit } \\
\text { (second/flower) }\end{array}$ & $\mathrm{n}$ & $\begin{array}{l}\text { Mean number of pollen } \\
\text { grains on moth proboscis }\end{array}$ & $\mathrm{n}$ \\
\hline \multicolumn{5}{|l|}{ Pyralidae } \\
\hline 1. Xanthomelaena schematias & $30.64 \pm 4.59$ & 11 & $3.86 \pm 1.30$ & 17 \\
\hline 2. Salma sp. & $27.25 \pm 3.12$ & 4 & $18.17 \pm 10.85$ & 6 \\
\hline 3. Sameodes cancellalis & $26.14 \pm 5.46$ & 7 & $17.67 \pm 2.60$ & 3 \\
\hline 4. Endotricha spp. & $29.75 \pm 5.20$ & 8 & $16.29 \pm 5.36$ & 9 \\
\hline 5. Crypsiptya sp. & $26.33 \pm 4.07$ & 6 & $5.80 \pm 2.24$ & 5 \\
\hline 6. Gadessa nilusalis & $24.22 \pm 4.24$ & 9 & $8.25 \pm 3.87$ & 4 \\
\hline \multicolumn{5}{|l|}{ Noctuidae } \\
\hline 7. Parallelia rigidistria & $20.59 \pm 4.49$ & 7 & $25.57 \pm 8.01$ & 7 \\
\hline \multicolumn{5}{|l|}{ Arctiidae } \\
\hline 8. Ceryx imaon & $21.75 \pm 4.99$ & 4 & $9.67 \pm 4.91$ & 3 \\
\hline 9. Cyana spp. & $20.60 \pm 5.59$ & 5 & $11.25 \pm 1.80$ & 4 \\
\hline \multicolumn{5}{|l|}{ Geometridae } \\
\hline 10. Cleora alienaria & $21.67 \pm 7.43$ & 6 & $10.67 \pm 2.19$ & 3 \\
\hline
\end{tabular}

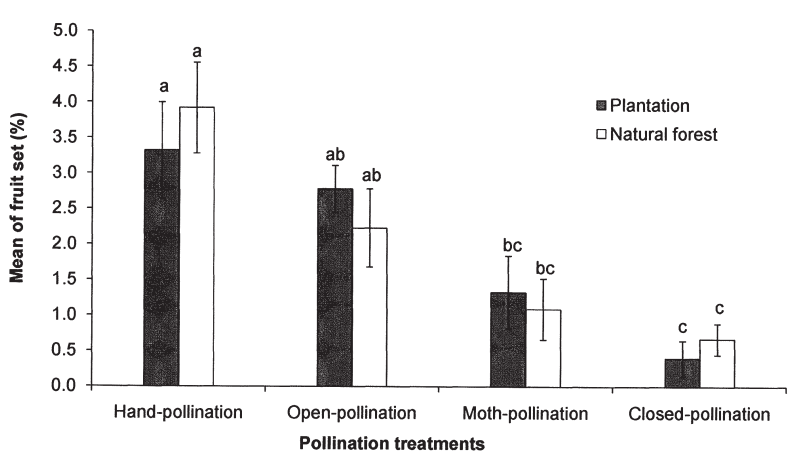

Fig. 5. Percentage of mean A. crassna fruit setting in hand pollination, open pollination, closed pollination, and moth pollination treatments. Means of each variable with the same letter are not significantly different at $P<0.05$ as determined by Duncan's New Multiple Range Test. Vertical bars represent standard error.

\section{DISCUSSION}

These observations showed that the number visitors of $A$. crassna flowers were about hundred species of nocturnal and diurnal insects. In comparison, only 20 species, half of which were nocturnal, visited Aquilaria flowers at plantation plots in Bogor, Indonesia (Soehartono and Newton, 2001). The insect visitors at the $A$. crassna study sites at Khao Yai National Park and the plantation at Trat Province are far more diverse.

Species diversity was analyzed by Shannon's index of species diversity and the species abundance was finding out by Margalef's index. The results showed that the visitor diversity in the natural forest was higher than in the plantation sites. Chey et al. (1997) found similar a species diversity of moths in plantations and natural forest, while Tangmitcharoen et al. (2006) reported higher diversity and abundance of insects in teak (Tectona grandis L.f.) canopies in natural forest than in planta- tions during the flowering season.

The results suggest that the quality and quantity of nectar secreted have important effects on insect foraging behavior. The same relationship between nectar and frequency of visitors has been reported in other flowers (Alekseyeva and Bureyko, 2000; Cawoy et al., 2008), and nectar properties are among the parameters affecting pollination and fruit setting (e.g. Cresswell, 1999; Shafir et al., 2003; Leiss et al., 2004; Kudo and Harder, 2005). The stigma of $A$. crassna flowers is receptive to pollen for at least the first 12 hours of flowering, and the most receptive period is from 18:00 to 21:00 (Sangtabtim, 2008). If insect visitors contribute to pollination of $A$. crassna flowers, there are distinct and different opportunities for pollination in night time and in day time. Therefore, we divided the insect visitors into two groups: nocturnal visitors, and diurnal visitors. Nocturnal visitors are mainly moths, and they are highly efficient pollinators of $A$. crassna in the early flowering period (night time) in both the natural forest and plantation sites. Moths are also important pollinators in Aquilaria spp. in Indonesia (Soehartono and Newton, 2001) and in Struthiola ciliate (Thymelaeaceae) in southern Africa (Makholela and Manning, 2006).

In this study, moths seem to be the most important visitors, especially noctuids and pyralids. The moth may be also transferring of pollen from anthers to stigma by the proboscis. However, Okamoto et al. (2008) stated that moths carried lower number of pollen grains but still moths are important pollinator because their visitation behavior is suitable for preventing geitonogamous pollination. So this quotation is inadequate. Pollen grains can be mostly observed on the tip of the proboscis (Sugiura and Yamazaki, 2005; Makholela and Manning, 2006), and the proboscis of moths is usually used for feeding on nectar and for carrying pollen to flowers (Proctor et al., 1996; Sugiura and Yamazaki, 2005). The moth visitors 
play a role in moving pollen to and from flowers within and among plants, thereby influencing the reproductive success of the plants (Talavera et al., 2001).

Results of the pollination experiments indicated that the A. crassna flowers for fruit succession are required for transferring of pollen to stigma by some vectors. Fruit setting was limited in moth pollinated flowers, which was associated with fewer flowers being left open to other insect visits. Visitor efficiency can be defined as the amount of pollen deposited on a stigma relative to the vector pollen load (Inouye et al., 1994), and the number of pollen grains on the proboscis of the moths may not be sufficient to disperse deposits on the $A$. crassna stigma.

Diurnal visitors (including wild bees, butterflies, wasps, flies and beetles) are potentially effective agents for $A$. crassna pollination and successful reproduction. The plants may be visited by multiple types of pollinators which transfer pollen between flowers with varying efficiency (Fishbein and Venable, 1996), and therefore, the insect visitors are necessary for $A$. crassna pollination.

In conclusions, the visitors to A. crassna flowers at the study sites include a diverse range of insects, and their visits are concentrated in particular periods of the night and morning. Moths are the major insect visitors, and play an important role in the pollination of $A$. crassna. The diversity and abundance of insect pollinators depends on several factors, including geographic and climatic conditions. Result of hand-pollination suggest that maximum fruit set of $A$. crassna is $3-4 \%$ in this field. So, great increase of fruit set would not be expected if pollination status is favor. Thus, the chances of pollination can be improved by pollinators, leading to an increase in fruit setting of $A$. crassna, which is a typically low fruit setting hermaphroditic plant species (Stephenson, 1981; Sutherland, 1986; Guitian, 1993). Therefore, to conservation and artificial supplementation of efficient pollinators could be an alternative way to increase fruit production in A. crassna seed plantations.

\section{ACKNOWLEDGEMENTS}

We acknowledge the support to Kasetsart University Research and Development Institute (KURDI), Thailand. We thank Mr. Pravatsart, C. and chief at Kao Yai National Park for providing the field facility. We are grateful to Mr. Pumpuang, S. and Ms. Sangtabtim, S. who assisted with data collection during field work. We also wish to thank family of Mr. Somporn owners of A. crassna plantation at Trat province for kindly providing study area. This research would not have been possible without material and equipment from the Faculty of Forestry, Kasetsart University, Thailand and Institute of Tropical Agriculture, Kyushu University, Japan.

\section{REFERENCES}

Alekseyeva, E. S. and A. L. Bureyko 2000 Bee visitation, nectar productivity and pollen efficiency of common buckwheat. Fagopyrum, 17: 77-80

Cawoy, V., J. M. Kinet and A. L. Jacquemart 2008 Morphology of nectarines and biology of nectar production in the distylous species Fagopyrum esculentum. Ann. Bot., 102: 675-684

Chey, V., J. Holloway and M. Speight 1997 Diversity of moths in forest plantations in Sabah. Bull. Entomol. Res., 87: 371-385

Cox, P. A. and R. B. Knox 1988 Pollination postulates and twodimensional pollination in hydrophilous monocotyledons. Ann. Missouri Bot. Gard., 75: 811-818

Cresswell, J. E. 1999 The influence of nectar and pollen availability on pollen transfer by individual flowers of oil-seed rape (Brassica napus) when pollinated by bumblebees (Bombus lapidaries). J. Ecol., 87: 670-677

DNP (Department of National Park, Wildlife and Plant Conservation, Thailand) 2005 National Park and World Heritage [cited 11 October 2007]. Available from: http:// www.dnp.go.th

Donovan, D. and R. Puri 2004 Learning from traditional knowledge of non-timber forest products: Penan Benalui and the autecology of Aquilaria in Indonesian Borneo. Ecol. Soc. 9 (3) [cited 11 October 2008]. Available from: http://www. ecologyandsociety.org/vol9/iss3/art3/

Fishbein, M. and D. L. Venable 1996 Diversity and temporal change in the effective pollinators of Asclepias tuberose. J. Ecol., 77: 1061-1073

Galen, C. and R. C. Plowright 1985 The effects of nectar level and flower development on pollen-carryover inflorescences of fireweed (Epilobium angustifolium) (Onagraceae). Canadian J. Bot., 63: 488-419

Ghazoul, J. 1997 The pollination and breeding system of Dipterocarpus obtusifolius (Dipterocarpaceae) in dry deciduous forests of Thailand. J. Nat. Hist., 31: 901-916

Ghazoul, J., K. A. Liston and T. J. B. Boyle 1998 Disturbanceinduced density-dependent seed set in Shorea siamensis (Dipterocarpaceae), a tropical forest tree. J. Ecol., 86: 462230

Guitian, J. 1993 Why Prunus mahaleb (Rosaceae) produces more flowers than fruits. Am. J. Bot., 80: 1305-1309

Heinrich, B. and P. H. Raven 1972 Energetics and pollination ecology. Science, 176: 597-602

Inouye, D. W., D. E. Gill, M. R. Dudash and C. B. Fenster 1994 A model of lexicon for pollen fate. Am. J. Bot., 81: 1517-1530

Kato, M., A. Takimura and A. Kawakita 2003 An obligate pollination mutualism and reciprocal diversification in the tree genus Glochidion (Euphorbiaceae). Proceedings of the national Academy of Science, USA, 100: 5264-5267

Khangsap, S. and C. Watcharinrath 2005 Mai Kritsana, possibility to economic plantation. Research Paper of Trat Agroforestry Station, Kasetsart University, Bangkok (In Thai)

Kudo, G. and L. D. Harder 2005 Floral and inflorescence effects on variation in pollen removal and seed production among six legume species. Funct. Ecol., 19: 245-254

Lau, J. A. and L. F. Galloway 2004 Effects of low-efficiency pollinators on plant fitness and floral trait evolution in Campanula Americana (Campanulaceae). Oecologia, 141: $577-583$

Leiss, K. A., K. Vrieling and P. L. G. Klinkhamer 2004 Heritability of nectar production in Echium vulgare. Heredity, 92: 446-451

Luwig, J. A. and J. F. Reynolds 1988 Statistical ecology: A primer on methods and computing. John Wiley and Sons, New York

Magurran, A. E. 2004 Ecological diversity and its measurement. Princeton University Press, New Jersey

Makholela, T. and J. C. Manning 2006 First of moth pollination in Struthiola ciliate (Thymelaeaceae) in Southern Africa. S. Afr. J. Bot., 72: 597-603

Moeller, D. A. 2005 Pollinator community structure and sources of spatial variation in plant-pollinator interactions in Clarkia xantiana ssp. xantiana. Oecologia, 142: 28-37 
Nghia, N. H. 1998 Aquilaria crassna. In: IUCN (2007) 2007 IUCN Red List of Threatened Species [cited 31 October 2007]. Available from: http://www.iucnredlist.org

Okamoto, T., A. Kawakita and M. Kato 2008 Floral adaptations to nocturnal moth pollination in Diplomorpha (Thymelaeaceae). Plant Species Biol., 23: 192-201

Phengklai, C. and S. Khamsai 1985 Some non-timber species of Thailand. Thai Forest Bull. (Botany), 1(15): 108-148

Proctor, M., P. Yeo and A. Lack 1996 The natural history of pollination. Timber Press, Portland

Richards, P. W. 1996 The tropical rain forest, $2^{\text {nd }}$ Edition. Cambridge University Press, Cambridge

Sangtabtim, S. 2008 Development of flower and fruit of Kritsana (Aquilqria crassna Pierre ex Lec.). M.Sc. Thesis, Kasetsart University, Bangkok, Thailand (In Thai with English Abstract)

Shafir, S., A. Bechar and E. U. Weber 2003 Cognition-mediated coevolution context-dependent evaluations and sensitivity of pollinators to variability in nectar rewards. Plant Syst. Evol., 238: 195-209

Soehartono, T. and A. C. Newton 2001 Reproductive ecology of Aquilaria spp. in Indonesia. For. Ecol. Manage., 152: $59-71$

Stephenson, A. G. 1981 Flower and fruit abortion: proximate causes and ultimate functions. Ann. Rev. Ecol. Syst., 12: $253-280$

Sugiura, S. and K. Yamazaki 2005 Moth pollination of Metaplexis japonica (Apocynaceae): pollination transfer on the tip of the proboscis. J. Plant Res., 118: 257-262

Sutherland, S. 1986 Floral sex ratio, fruit set, and resource allocation in plants. J. Ecol., 67: 991-1001

Talavera, S., F. Bastida, P. L. Ortiz and M. Arista 2001 Pollinator attendance and reproductive success in Cistus libanotis L. (Cistaceae). Int. J. Plant Sci., 162: 343-352
Tangmitcharoen, S., T. Takaso, S. Siripatanadilox, W. Tasen and J. N. Owens 2006 Insect biodiversity in flowering teak (Tectona grandis L.f.) canopies: Comparison of wild and plantation stands. For. Ecol. Manage., 222: 99-107

Tasen, W., S. Tangmitcharoen and D. Wiwatwitaya 2000-2002 The role and behavior of some major insect pollinators on pollination of Teak flowers (Tectona grandis Linn.F.) Thai J. Forestry, 19-21: 52-64 (In Thai with English Abstract)

TDRI (Thailand Development Research Institute) 1995 Green finance: A case study of Khao Yai. Natural Resources and Environment Program, TDRI, Bangkok [cited 10 April 2008] Available from: http://www.tdri.or.th/library/quarterly/ text/ mingsarn.htm

Thaieasterncluster 2008 Logistics cluster of Trat Province [cited 10 April 2008]. Available from: http://www.thaieasterncluster.com/logistics/index.php?option=com_content\&ta sk $=$ view \&id $=10 \&$ Itemid $=18$

Thomson, J. D. 1986 Pollen transport and deposition by bumble bees in Erythronium: influences of floral nectar and bee grooming. J. Ecol., 74: 329-341

Tran, Q. L., Q. K. Tran, K. Kouda, N. T. Nguyen, Y. Maruyama, I. Saiki and S. Kadota 2003 A survey on A. crassna in Vietnam. J. Trad. Med., 20(3): 124-131

United Nations 1992-2007 UNESCO World Heritage Centre, All Rights Reserved I Terms / Policies I v3.0 [cited 11 Dec 2007]. Available from: http://whc.unesco.org/en/list/590

Whittaker, R. H. 1977 Evolution of species diversity in land communities. Evol. Biol., 10: 1-67

Whitehead, V. B., J. H. Giliomee and A. G. Rebelo 1987 Insect pollination in the Cape flora. In: Rebelo AG (ed.) A preliminary synthesis of pollination biology in the Cape flora, pp. 52-82. CSIR, Pretoria

Wolda, H. 1981 Similarity indices, sample size and diversity. Oecologia, 50: 296-302 